American Journal of Environmental Sciences 7 (4): 354-361, 2011

ISSN 1553-345X

(C) 2011 Science Publications

\title{
Groundwater Dynamics and Quality Assessment in an Agricultural Area
}

\author{
Stefano Lo Russo, Adriano Fiorucci and Bartolomeo Vigna \\ Department of Environment and Geo-Engineering, \\ Politecnico di Torino-DITAG Land, \\ C.so Duca Degli Abruzzi, 2410129 Torino, Italy
}

\begin{abstract}
Problem statement: The analysis of the relationships among the different hydrogeological Units and the assessment of groundwater quality are fundamental to adopt suitable territorial planning measures aimed to reduce the potential groundwater pollution especially in agricultural regions. In this study, the characteristics of groundwater dynamics and the assessment of its quality in the Cuneo Plain (NW Italy) were examined. Approach: In order to define the geological setting an intense bibliographic analysis has been performed by the authors. This analysis was implemented by several correlated land controls and specific surveys that have permitted to analyze to certain reliability the Quaternary evolution of the entire plain sector and the current relationships among the different geological bodies that strongly affect the groundwater dynamics. Results: The Quaternary alluvial deposits overlap a Tertiary sedimentary succession through a series of erosional unconformity surfaces. These Quaternary deposits highlight a variable thickness ranging from 80-100 $\mathrm{m}$ in the foothills of the mountains up to a few meters in the more distal portion of the plain. In these deposits there are several unconfined aquifers which are not hydraulically interconnected due to the deep fluvial incisions that reach the underlying tertiary substrate. The Cuneo plain is intensively populated and lot of villages and farms characterize the landscape. In the overall area it is present an intensive agricultural and livestock activity predominantly represented by crops of wheat and corn and farms of cattle and pigs. All these activities represent point and diffuse groundwater pollution sources and require a considerable amount of groundwater which is withdrawn from the Quaternary aquifers by means of thousands of water wells. The groundwater quality is strongly influenced by the content of nitrates and manganese. The nitrates are linked to pollution due to agricultural activities and livestock and increase along the groundwater flow lines. The manganese content is quite high in the foothills of the mountains and in some restricted areas of the plain and appears to be linked to the natural litho logical composition of the aquifers. Conclusion: Due to high degree of intrinsic aquifers vulnerability over the entire Cuneo plain sector in order to reduce the actual groundwater pollution and the risk for human health it has to be planned several territorial suitable planning actions aimed to limit nitrates effluents and livestock untreated discharges according with the European rules.
\end{abstract}

Key words: Quaternary aquifers, groundwater dynamics, nitrate pollution, agricultural activities, cuneo plain

\section{INTRODUCTION}

To correctly assess the planning actions to be implemented in order to reduce the groundwater pollution risk, the hydrogeological setting and the groundwater dynamics have to be evaluated at an early stage of any territorial analysis (Bianchi-Fasani et al., 2011).

The accurate analysis of the relationships among the different hydrogeological Units and the assessment of the groundwater quality are fundamental to adopt suitable territorial planning measures aimed to reduce the potential groundwater pollution by means of land use restrictions (Ashraf $e t$ al., 2011; Cheong et al., 2011; Hamilton and Helsel, 1995; Lo Russo and Taddia, 2009; Nouri and Malmasi, 2005). Moreover, the preliminary hydrogeological analysis is essential in the areas that are strongly impacted by anthropogenic sources such as the agricultural areas in the developed countries.

Corresponding Author: Stefano Lo Russo, Department of Environment and Geo-Engineering, Politecnico Di Torino-DITAG Land, C.so Duca Degli Abruzzi, 2410129 Torino, Italy 


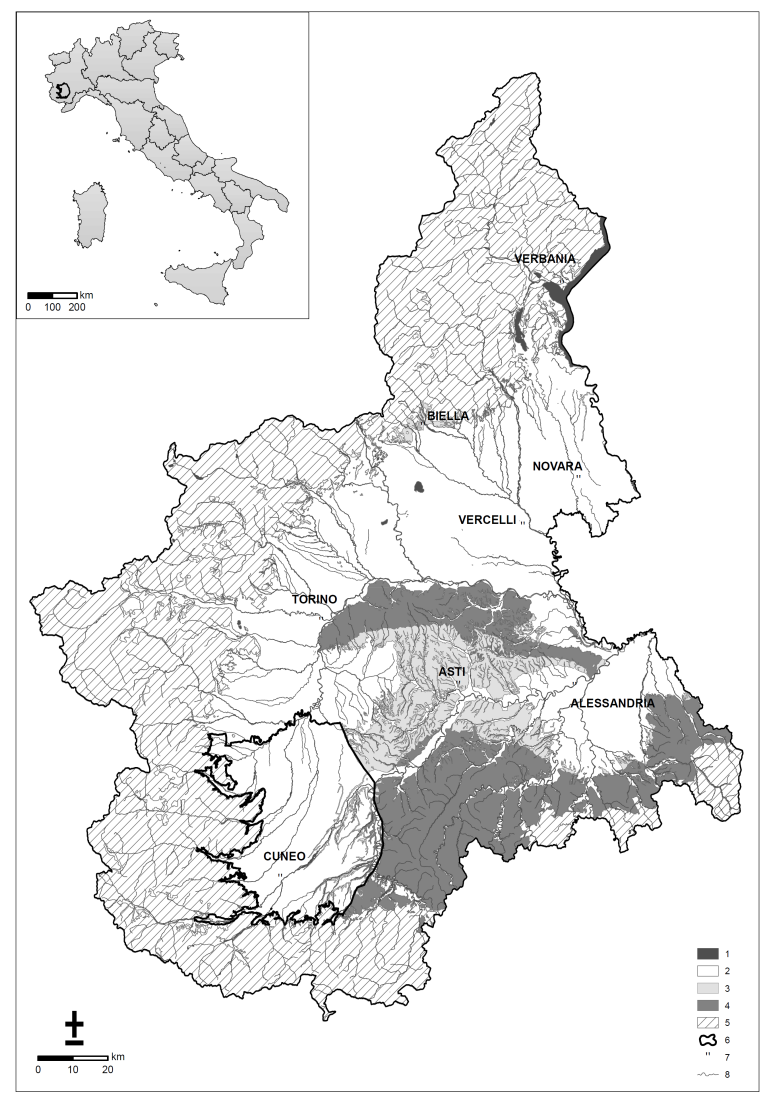

Fig. 1: Location of examined area (1) Main lakes, (2) Quaternary alluvial deposits; (3) Pliocene deposits; (4) Oligo-Miocene deposits; (5) Alpine basement; (6) Cuneo plain boundary; (7) Main towns; (8) Main rivers

In fact, nitrate, one of the most common pollutants in groundwater, causes a significant water-quality issue worldwide, especially in agricultural regions (Bohlke and Denver, 1995; Silva et al., 2000). Nitrate can originate from various anthropogenic sources, such as fertilizers, animal manure, domestic waste water and septic tanks, as well as organic nitrogen from soil (Aravena et al., 1993; Fogg et al., 1998; Hakim et al., 2009; Min et al., 2002; Wang and Yang, 2008). Thus, the risk assessment of groundwater by nitrate becomes increasingly important (Pham et al., 2011; Sacco et al., 2007).

In this study, the characteristics of groundwater dynamics and the assessment of its quality in the Cuneo Plain (NW Italy) were examined by an analysis of the principal Quaternary hydrogeological Units, their geometrical, structural and hydrogeological relationships and by an extensive groundwater quality survey across the province.
The examined area $\left(1.790 \mathrm{~km}^{2}\right)$ consists of a large plain crossed by the Stura di Demonte river and covers a vast portion of the Piedmont territory. It falls roughly between the Langhe and Roero Hills to the east, the Alps to the south and west and the Turin plain to the north (Fig. 1). Within this sector several geomorphological units are identifiable such as the main plain, the valleys bottom and the related terraces, the uplands and the ancient alluvial fans.

The main plain was originated by the deposition of coarse sediments, with a sandy-silt matrix, belonging to a series of large coalescing alluvial fans, originated by the main water courses flowing from the mountain sector in this wide area. The water courses located in the northern portion of the area belong to Po river catchment area while the hydrographical network of the southern portion flows into the Tanaro river basin. In the plain sector belonging to the Tanaro river catchment basin it is possible to observe a relatively recent rapid deepening of the main watercourse and its tributaries, which now flow deeply in the plain. These phenomenons affect both the Quaternary alluvial deposits and the underlying Tertiary succession.

In the Tanaro river basin the valleys bottom and the related terraces are represented by a narrow range of recent alluvial deposits which are segmented in a various orders of terraces. A series of uplands and ancient alluvial fans mainly located at the foot of the alpine mountain chain and in some isolated part of the plain are also present at a more elevated altitude as compared to the fundamental level of the plain.

\section{MATERIALS AND METHODS}

Geological setting-Quaternary units: In order to define the geological setting an intense bibliographic analysis of local historical geology investigations has been performed by (Conti et al., 2000; Vigna et al., 2010; Zuppi and Sacchi, 2004). This analysis and the correlated land controls and specific surveys have permitted to reconstruct to certain reliability the Quaternary evolution of the entire plain sector and the present relationships among the different geological bodies which strongly affect the hydrogeological relationships and the groundwater dynamics.

The Quaternary alluvial plain overlays the Pliocene sediments (Tertiary substrate) and develops in a subsident basin located between the Alpine basement (to the $\mathrm{W}$ and $\mathrm{S}$ ) and the Langhe hills (to the E) (Fig. 2). 


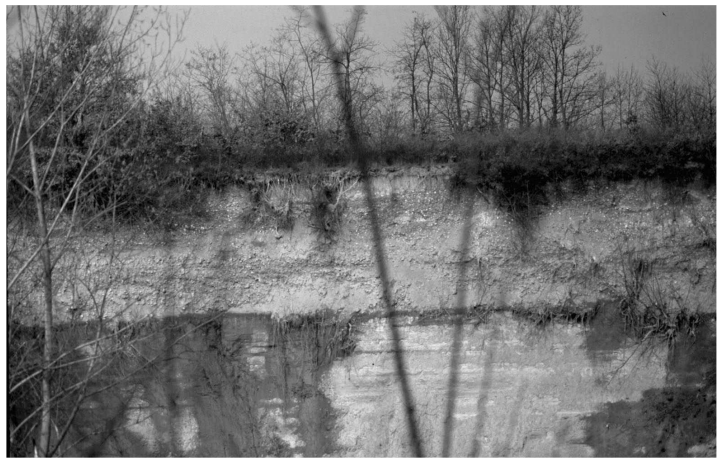

Fig. 2: Example of a contact between the overlaying Quaternary deposits and the Miocene substrate

The depositions of the Quaternary floods have been heavily influenced by several tectonic factors and the fluvial dynamics. As a matter of fact, during this period a series of weak uplifting events have affected the Cuneo southern sector, resulting in the deepening of the entire river network and conditioning important phenomena such as the Tanaro river diversion. The result of this complex evolution is a number of evident erosion surfaces, which develop at different stratigraphic position. They have similar sedimentary environments and identify several Units that are clearly distinguishable basing on the altitude, the particle size and degree of alteration of the clasts.

\section{RESULTS}

The different erosion, sedimentation and weathering phases are reflected in many morphological Units:

- Unit 1 of bottom valley deposits and related terraces

- Unit 2 of the main plain

- Unit 3 of ancient terraces

The Unit 1 of bottom valley deposits and related terraces outcrops mainly along the slopes of the rivers flowing in the catchment area of the Tanaro river basin. This Unit is the result of a series of progressive deepening of the river network phenomena and subsequent deposition of a small layer of sediments connected to the diversion of the Tanaro river which occurred after the formation of the main Cuneo plain. The lithology consists of coarse unaltered gravel, with scarce sandy matrix and a silty-sandy soil, very thin (50 $\mathrm{cm}$ ) that is present on the terraces and in areas farther away from the river beds. In many portion of the examined areas the Tanaro river and its tributaries flow directly on the Pliocene and Miocene Units and the thickness of alluvial deposits is negligible or absent.

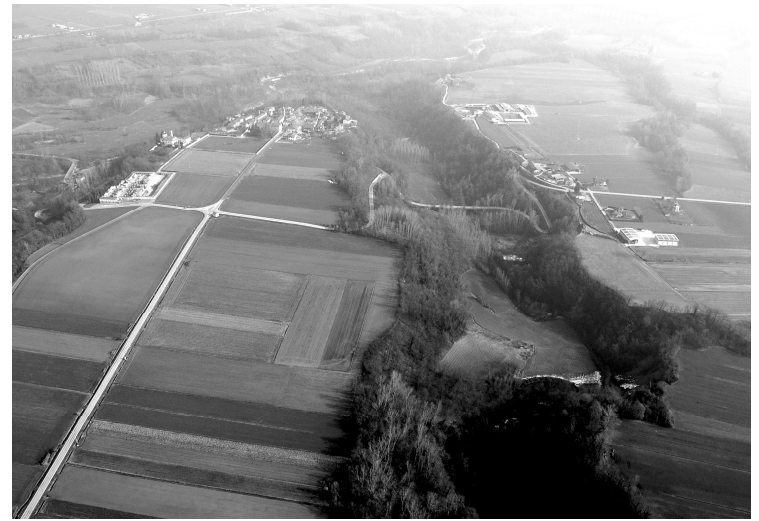

Fig. 3: Segmentation of the main plain due to the river network deepening

The Unit 2 of the main plain outcrops in the left and the right bank of the Stura river to the confluence with the Tanaro river. The whole plain corresponds to the Tanaro river basin. Due to the deepening of several waterways (river Stura, Gesso, Pesio, Ellero, Corsaglia, Mongia and Tanaro) the plain was segmented into several different sub-areas. These rivers currently run embedded in the Miocene or Pliocene substrate, several tens of meters below the fundamental level of the plain (up to 80-90 $\mathrm{m}$ in the case of the Stura river) (Fig. 3).

The thickness of the main plain deposits (Unit 2) ranges from 40-100 m near the main Alpine valleys, up to $7-8 \mathrm{~m}$ in more distal areas of the plain, like those facing the Langhe and Roero hills. This Unit consists of coarse gravels with cobbles up to $20-30 \mathrm{~cm}$ in diameter, with a patina of alteration, surrounded by a sandy-silty matrix. The overlaying soil is constituted by brown sandy-silty clay about 1 meter thick. In the area between the Stura and Maira rivers several thick cemented horizons are present while, on the northern border with the Turin plain, the gravels are covered by a $10-15 \mathrm{~m}$ thick clay-loam horizon related to lacustrine environment. The Unit belongs to the sandy-gravel deposits (Fluvial and Fluvioglacial Riss, Fluvial Würm and Recent Floods). It is not possible to distinguish the oldest sediments (Fluvial Riss) from the most recent (Fluvial Würm). Through an important erosional surface the Unit 2 overlays the deposits belonging to the Pliocene succession and the Oligo-Miocene succession to the eastern part.

The Unit 3 outcrop at high terraces isolated on the plain, along the alpine relief and at the main Poirino plateau (near the Roero hills). It represents the old level of the alluvial deposits of the Middle-Upper Pleistocene (?) which was deposited on the area located between the Alpine basement and the Langhe hills. 


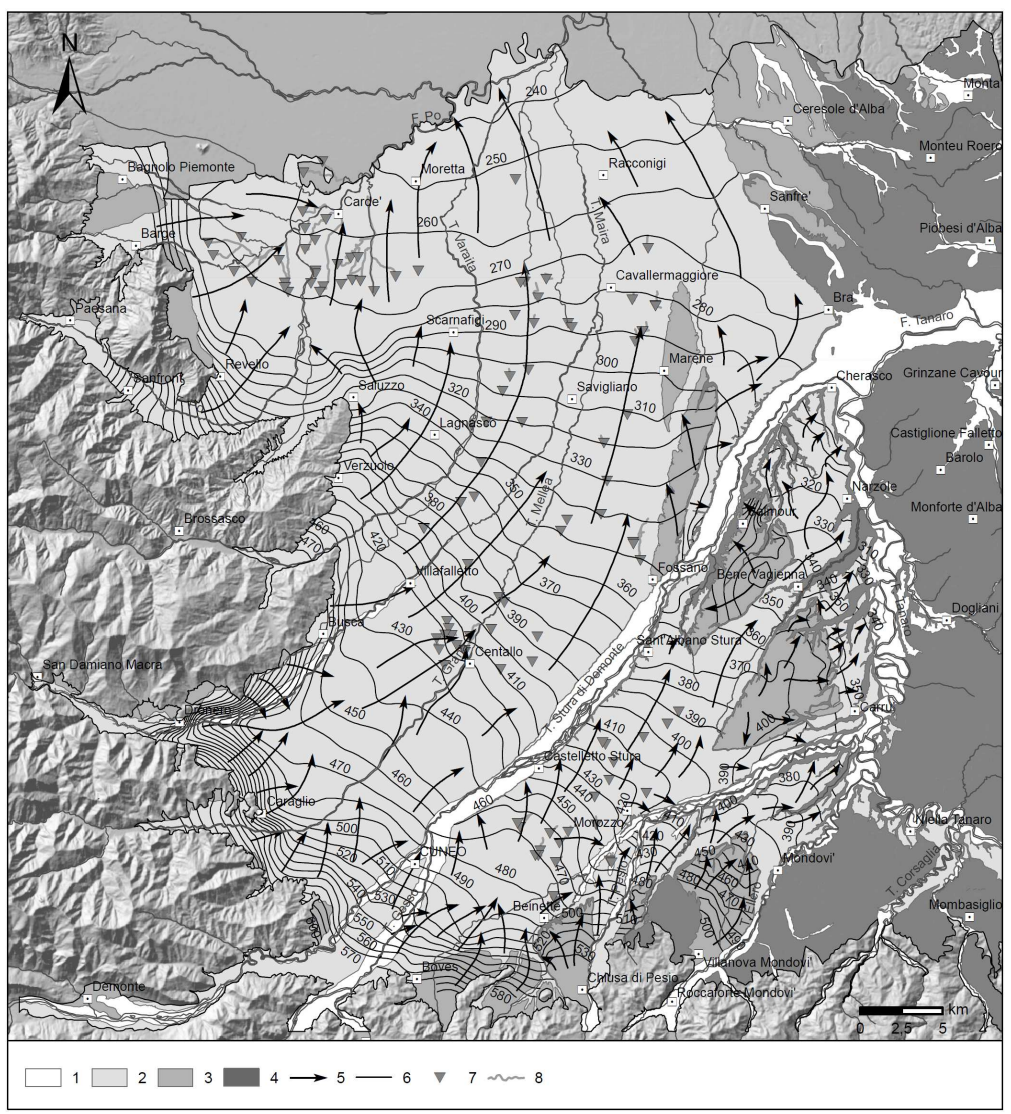

Fig. 4: Hydrogeological sketch map of the investigated area (1) Unit of bottom valley deposits and related terraces; (2) Unit of the main plain; (3) Unit of ancient terraces; (4) Tertiary sediments; (5) Groundwater flow direction; (6) Potentiometric surface contour lines and their elevation a.s.l.-equidistance $10 \mathrm{~m}$; (7) Springs; (8) Main rivers)

Its thickness is rather small, usually less than $10 \mathrm{~m}$. These sediments were then affected by a series of erosional events probably related to the final stages of the uplifting of the whole southern area and partly erased. The Unit 3 mainly consists of very heterogeneous gravels with abundant silty-clay matrix. The pebbles reach a significant size to more than $1 \mathrm{~m}$ in diameter in the areas near the basement whereas, in the more distal portion, the particle size is significantly reduced. The soil is characterized by a thick alteration layer (about $2 \mathrm{~m}$ ) of reddish-purple silty clay (named Ferretto), followed by gravels which are intensely altered to several meters in depth. Each terrace is joined with the main valley through steep or gentle slopes with topographic difference in height between 5 and $30 \mathrm{~m}$. This unit overlies the Pliocene Units and, marginally, the Miocene deposits. The lower contact is marked by an evident erosional surface (Fig. 4).

\section{DISCUSSION}

Hydrogeological setting and groundwater dynamics: In the Cuneo plain, several unconfined aquifers were identified. They are hosted into different hydrogeological Units and separated by extensive and continuous outcrops of the Miocene - Pliocene substrate sediments located along the river's deep cuts.

The substrate is characterized by a very low level of permeability and defines a limit of permeability that conditions the main direction of the groundwater flow for the aquifers hosted into the overlaying Quaternary alluvial deposits. The limits among the different hydrogeological Units are detectable along the main embankments of the rivers that cross the Cuneo plain in the right respect the Stura river.

Each Unit belonging to the Quaternary hydrogeological Series usually hosts unconfined aquifers, distinguished by geometry and topographic elevation which are characterized by a specific recharge- 
discharge mechanism and a dominant hydrogeochemical facies. The bottom of the different aquifer systems corresponds to the discontinuity surfaces that separate the Quaternary Units from the Pliocene, Miocene Units and from the Alpine basement depending from the geographical and stratigraphical position.

Basing on the collected geological data and their interpretation several hydrogeological Units grouped into two main hydrogeological series, namely Basal Series and Quaternary Series, have been recognized.

The Basal Series consists of siliciclastic deposits of the Tertiary Piedmont Basin (Oligocene-Pliocene) is not described in this work. On the contrary, the Quaternary Series is characterized by three main hydrogeological Units.

The Unit 1 of bottom valley deposits and related terraces has a very high permeability, but due to the very low thickness, hosts very limited aquifers.

The main Alluvial Unit (Unit 2) generally highlights an overall high hydraulic permeability. In some limited areas it is observed a decrease in permeability where the sediments are cemented or the silty matrix is abundant. The Unit hosts several aquifers which are usually unconfined and recharged by the rainfall and the important losses of the main streams downflowing from the alpine valleys. In the dry seasons (winter and summer) several watercourses (Torrente Gesso, Torrente Grana, Po River) become totally dry near their entrance into the plain due to the flow losses and only after several kilometres downstream, it is possible to observe the presence of surface flow due to alimentation coming from the groundwater.

The plain is subdivided into two main areas separated by the course of the Stura river whose deepening intersect the underlying Pliocene succession and separate the Unit. On the left of the Stura river the overall aquifer is continue while on the Stura river right the aquifers are hydraulically separated due to the deeper cuts of different tributaries streams.

The main Alluvial Unit hosts the major aquifers which are exploited by thousands of wells for irrigation, industry and human consumption. The wells drilled in the proximity of the alpine chain, where the depth to groundwater exceed $50 \mathrm{~m}$, showed no special relationships with precipitation and a seasonal annual variation over $4-5 \mathrm{~m}$. In the central plain the depth to groundwater strongly reduces and it is detectable a close relationships between the variation of the groundwater levels and the precipitation. In these areas the annual oscillations of the piezometric surface is smaller than $2 \mathrm{~m}$.

The potentiometric surface (Fig. 4) has been defined by means of over 1700 measurements in wells, piezometers and streams. The groundwater flow directions are strictly determined by the geometry of the underlying Tertiary substrate and by the river cuts when they intercept the substrate. The Piedmont regional monitoring network (piezometers, meteo-climatic network and flow levels on the main rivers) allows to reconstruct the correlation between the recharge and the underground flow.

In the plain area where the unconfined groundwater potentiometric surface is very close to the topographic surface there are numerous springs and drainage trenches (over 100 are recorded). In these areas, since the XII century several major drainage works have been carried out in order to drain extensive parts of the plain where the wetlands were present. These drained groundwater combined with several wells, are abundantly used for irrigation. On the contrary the drinking water wells exploiting those aquifers have to treat the groundwater due to the bad water quality for the human consumption.

The ancient Alluvial Gravel Unit 3 corresponds to the ancient alluvial fans and the ancient terraces and is characterized by a medium level of hydraulic permeability related to the presence of very coarse gravels with pebbles mixed with an abundant silty matrix. In the areas where these sediments overlay lithotypes slightly permeable or impermeable (Pliocene and Miocene clays) a thin unconfined aquifer is usually present. It is generally characterized by a radial flow lines drainage pattern directed to the edges of the terraces. Elsewhere, where the Pleistocene gravels overlay sediments which are characterized by comparable hydraulic permeability values (Pliocene sands and gravels), no aquifer is present. Because of the particular morphology of the terraces each morphological unit hosted an isolated aquifer which is recharged uniquely by rainfall or irrigation water.

These unconfined aquifers have a very low productivity due to two main factors: a very small recharge and a low permeability of the deposits. The recharge is supplied solely by rainfall because generally there are no irrigation channels. Moreover the precipitation fall on a clay-loam thick impermeable soil and a certain amount of runoff develops to the border of the terraces without any infiltration. Therefore only few wells for agricultural purposes exploit such resources. Probably due to groundwater scarceness for irrigation and human consumption only few small villages are historically present on this area.

Geochemistry and groundwater quality: The groundwater geochemical characterization has been carried out through 205 chemical analysis of water sampled in the entire area under consideration (Fig. 5). 


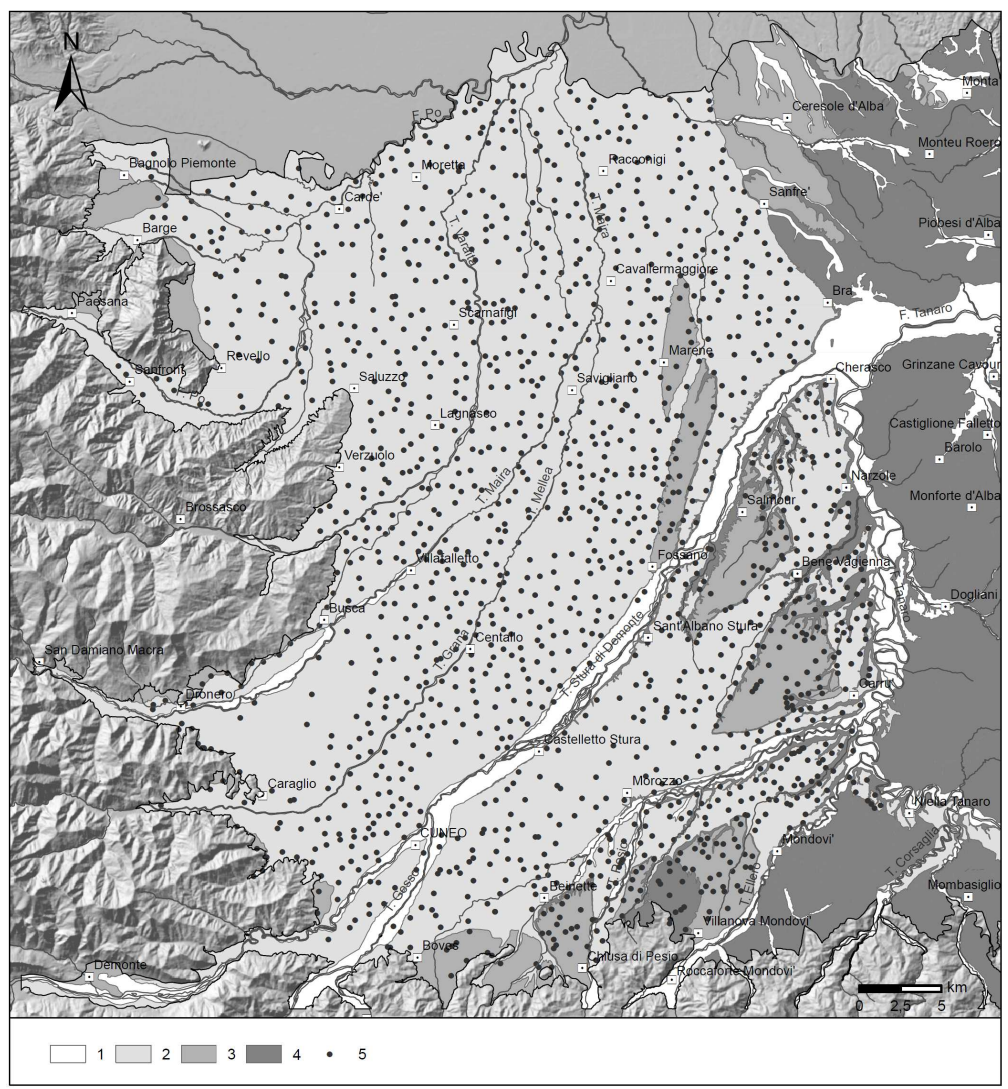

Fig. 5: Groundwater monitoring network (1) Unit of bottom valley deposits and related terraces; (2) Unit of the main plain; (3) Unit of ancient terraces; (4) Tertiary sediments; (5) Monitoring wells

Groundwater are essentially a chemistry type $\mathrm{HCO}^{3-}>\mathrm{SO}_{4}^{2-}>\mathrm{Cl}^{2-}-\mathrm{Ca}^{2+}>\mathrm{Mg}^{2+}>\left(\mathrm{Na}^{+}+\mathrm{K}^{+}\right)$. Rarely it is possible to find chemistry type $\mathrm{HCO}^{3-}>\mathrm{SO}_{4}{ }^{2-}>\mathrm{Cl}^{-}-$ $\mathrm{Mg}^{2+}>\mathrm{Ca}^{2+}>\left(\mathrm{Na}^{+}+\mathrm{K}^{+}\right)$.

The quality of groundwater is strongly influenced by the nitrate presence with concentrations ranging from 2.2-152.9 $\mathrm{mg} \mathrm{L}^{-1}$. In general, it is observed an increasing trend for the nitrates concentration in the direction of groundwater flow lines. This phenomenon is probably due to an insufficient dilution capacity of the aquifer or to an exceeding load of nitrogen pollutants respect for this capacity.

The nitrate level is below $10 \mathrm{mg} \mathrm{L}^{-1}$ only in the alimentation zones where the aquifers are supplied by the mountain torrents. Along the mountain foothills and near the areas where the rivers losses supply the aquifer, the nitrate levels range from $10+20 \mathrm{mg} \mathrm{L}^{-1}$. Similar values are found also in the areas facing the Langhe and Roero hills where the aquifer has a very limited thickness and the wells intercept also a deeper aquifer. In most of the plain the nitrate value is between 20-60 $\mathrm{mg} \mathrm{L}^{-1}$ indicating a strong anthropogenic impact.
The monitoring points with concentrations of nitrate significantly anomalous $\left(>100 \mathrm{mg} \mathrm{L}^{-1}\right)$, can be considered as not representative and connected to specific pollution phenomena. These situations are really rare (7 out of 205 points analyzed) and located in areas where the aquifer is very thin. In general, however, it is really evident a serious harm for the groundwater quality circulating in the examined aquifers. Almost $48 \%$ of the area under consideration has a nitrate content exceeding $30 \mathrm{mg} \mathrm{L}^{-1}$. That percentage increases dramatically to $73 \%$ if we consider the nitrate levels greater than $25 \mathrm{mg} \mathrm{L}^{-1}$.

The manganese content is quite high in the foothills of the mountains and in some restricted areas of the plain and appears to be linked to the natural litho logical composition of the aquifers. The concentrations of manganese measured in some wells exceed the maximum admissible concentration for drinking water according to the Italian legislation (D. Lgs. 31/01 - 0.05

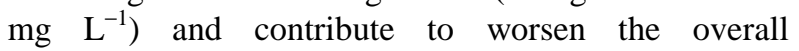
groundwater quality. 


\section{CONCLUSION}

The hydrogeological study of the Cuneo plain was performed through the acquisition and the processing of a series of interconnected data that permit to define the hydrogeological setting and to assess the basic groundwater resources quality. Based on the reconstruction of the stratigraphic and hydrogeological characteristics of the different bodies it has been recognized a Quaternary Series consisting of three hydrogeological Units.

The main plain unconfined aquifers represent the main water resource for the most common uses (irrigation and industry) and highlight a strong anthropogenic impact. On the contrary the aquifers hosted in the Unit 3 of ancient terraces and in the Unit 1 of bottom valley deposits and related terraces are not very productive because of their thinness and the limited recharge.

The Quaternary evolution highlighted a series of water courses deepening events followed by depositional phases that have generated several distinct hydrogeological areas. In particular, the Stura river divides the Cuneo plain into two main areas through a deep cut of over $80 \mathrm{~m}$ that intersect, for several tens of meters, even the Pliocene substrate.

The unconfined potentiometric surface highlights the important contribution of aquifer recharge from the losses of the main streams in the foothill areas with periods of complete drying up of the rivers. In the plain area several water courses are directly supplied by the aquifer and it is possible to detect many springs located on the permeability boundary between the underlying Tertiary substrate and the Quaternary alluvial deposits. The main groundwater flow is heavily influenced by the geometry of the substrate and is directed mainly towards NE: In the northern portion of the plain, the flow lines turn to NNW directed to the Po River.

The chemical status of the groundwater resources has been defined through a campaign of sampling and related laboratory tests that involved more than 200 water points belonging to the various aquifers. The quality is compromised by the presence of nitrates that can reasonably be attributed to the flourishing agrolivestock activities typical of the area. Several pig farms contribute to worse the pollution situation. The impact on the groundwater quality due to nitrogen compounds can be configured as a real injury. In fact, if we consider the other chemical parameters the groundwater quality ranges from good to excellent respect the Italian legislation with the exception of manganese. Due to high degree of intrinsic aquifers vulnerability over the entire Cuneo plain sector in order to reduce the actual groundwater pollution level and the risk for human health it has to be planned several territorial suitable planning actions aimed to limit nitrates effluents and livestock untreated discharges according with the European rules (WFD, 2000).

\section{ACKNOWLEDGEMENT}

The researchers wish to thank the environmental authority of the Piemonte region government that partially supported the study.

\section{REFERENCES}

Aravena, R., M.L. Evans and J.A. Cherry, 1993. Stable isotopes of oxygen and nitrogen in source identification of nitrate from septic systems. Ground Water, 31: 180-186. DOI: 10.1111/j.17456584.1993.tb01809.x

Ashraf, S., H. Afshari and A.G. Ebadi, 2011. Geographical information system techniques for evaluation of groundwater quality. Am. J. Agric. Biol. Sci., 6: 261-266. 2011. DOI: 10.3844/ajabssp.2011.261.266

Bianchi-Fasani, G., C. Esposito, M. Petitta, G. Scarascia-Mugnozza and M. Barbieri et al., 2011. The importance of geological models in understanding and predicting the life span of rockslide dams: The Case of Scanno Lake. Nat. Art. Rockslide Dams Lect. Notes Earth 323 Sci., 133. DOI: $10.1007 / 978-3-642-04764-0 \_11$

Bohlke, J.K. and J.M. Denver, 1995. Combined Use of Groundwater Dating, Chemical, and Isotopic Analyses to Resolve the History and Fate of Nitrate Contamination in Two Agricultural Watersheds, Atlantic Coastal Plain, Maryland. Water Resou. Res., 31: 2319-2339. DOI: 10.1029/95WR01584

Chen, J.J., Y.J. Chen, L.K. Teuschler, G. Rice and K. Hamernik et al., 2003. Cumulative risk assessment for quantitative response data. Environmetrics, 14: 339-353. DOI: 10.1002/env.587

Cheong, J.Y., S.Y. Hamm, J.H. Lee, K.S. Lee and N.C. Woo, 2011. Groundwater nitrate contamination and risk assessment in an agricultural area, South Korea. Environ. Earth Sci. DOI: 10.1007/s12665011-1320-5

Conti, A., E. Sacchi, M. Chiarle, G. Martinelli and G.M. Zuppi, 2000. Geochemistry of the formation waters in the Po Plain (Northern Italy): An overview. Applied Geochem., 15: 51-65. DOI: 10.1016/S0883-2927(99)00016-5 
Fogg, G.E., D.E. Rolston, D.L. Decker, D.T. Louice and M.E. Grismer, 1998. Spatial variation in nitrogen isotope values beneath nitrate contamination sources. Ground Water, 36: 418-426. DOI: 10.1111/j.1745-6584.1998.tb02812.x

Hakim, M.A., A.S. Juraimi, M. Begum, M. Hasanuzzaman and M.K. Uddin et al., 2009. Suitability evaluation of groundwater for irrigation, drinking and industrial purposes. Am. J. Environ. Sci., 5: 413-419. 10.3844/ajessp.2009.413.419

Hamilton, P.A. and D.R. Helsel, 1995. Effects of agriculture on ground-water quality in five regions of the United States. Ground Water, 33: 217-226. DOI: $10.1111 / \mathrm{j} .1745-6584.1995 . t b 00276 . x$

Lo Russo, S. and G. Taddia, 2009. Groundwater in the urban environment: Management needs and planning strategies. Am. J. Environ. Sci., 5: 494500. DOI: 10.3844/ajessp.2009.494.500

Min, J.H., S.T. Yun, K.J. Kim, H.S. Kim and J.S. Hahn et al., 2002. Nitrate contamination of alluvial groundwaters in the Nakdong river basin, Korea. Geosci. J., 6: 35-46. DOI: 10.1007/BF02911334

Nouri, J. and S. Malmasi, 2005. The role of groundwater vulnerability in urban development planning. Am. J. Environ. Sci., 1: 16-21. DOI: 10.3844/ajessp.2005.16.21

Pham, M.P.T., J.W. Castle and J.H. Rodgers, 2011. Application of water quality guidelines and water quantity calculations to decisions for beneficial use of treated water. Applied Water Sci., DOI: 10.1007/s13201-011-0012-3
Sacco, D., M. Offi, M. De Maio and C. Grignani, 2007. Groundwater nitrate contamination risk assessment: A comparison of parametric systems and simulation modelling. Am. J. Environ. Sci., 3: 117-125. DOI: 10.3844/ajessp.2007.117.125

Silva, S.R., C. Kendall, D.H. Wilkinson, A.C. Ziegler and C.C.Y. Chang et al., 2000. A new method for collection of nitrate from fresh water and the analysis of nitrogen and oxygen isotope ratios. J. Hydrol., 228: 22-36. DOI: 10.1016/S00221694(99)00205-X

Vigna, B., A. Fiorucci and M. Ghielmi, 2010. Relations Between Stratigraphy, Groundwater Flow and Hydrogeochemistry in Poirino Plateau and Roero Areas of the Tertiary Piedmont Basin. Mem. Descr. Carta Geol. d'It. 90: 267-292.

Wang, J.L. and Y.S. Yang, 2008. An approach to catchment-scale groundwater nitrate risk assessment from diffuse agricultural sources: A case study in the Upper Bann, Northern Ireland. Hydrol Proc., 22: 4274-4286. DOI: 10.1002/hyp.7036

WFD, 2000. Water Framework Directive. European Commision.

Zuppi, G.M. and E. Sacchi, 2004. Hydrogeology as a climate recorder: Sahara-Sahel (North Africa) and the Po Plain (Northern Italy). Global Planetary Change, 40: 79-91. DOI: 10.1016/S09218181(03)00099-7 